\title{
Effects of FGFR gene polymorphisms on response and toxicity of cyclophosphamide-epirubicin-docetaxel- based chemotherapy in breast cancer patients
}

Lu Chen ${ }^{1 \dagger}$, Huijie Qi ${ }^{1 \dagger}$, Liudi Zhang ${ }^{1}$, Haixia $\mathrm{Li}^{2}$, Jie Shao ${ }^{3}$, Haifei Chen ${ }^{1}$, Mingkang Zhong ${ }^{1}$, Xiaojin Shi ${ }^{1}$, Ting Ye ${ }^{4^{*}}$ and Qunyi $\mathrm{Li}^{i^{*}}$

\begin{abstract}
Background: The chemotherapy resistance and toxicity of chemotherapy are major problems in breast cancer treatment. However, candidate biomarkers for predicting clinical outcomes and better prognosis remain lacking.

Methods: In this study, we analyzed possible impact of 8 genetic variants of fibroblast growth factor receptor1-4 (FGFR1-4) on the treatment response and toxicities in 211 breast cancer patients. DNA was extracted from peripheral blood cells, and the genotypes were examined using the TaqMan Pre-Designed SNP Genotyping Assays.

Results: The FGFR4 rs1966265 and FGFR2 rs2981578 contributed to clinical outcome of breast cancer treated with docetaxel-epirubicin-cyclophosphamide (CET)-based chemotherapy. For rs1966265, AA genotype had significant correlation with the clinical response to neoadjuvant chemotherapy (NCT) when compared with GG and AG/GG genotype ( $P=0.019$ and $P=0.004$, respectively). Moreover, A allele of FGFR2 rs2981578 had significant rates of response $(P=0.025)$. In addition, rs2420946 CC genotype was associated with higher frequency of toxicities compared with $\Pi$ and $C T / T$ genotypes ( $P=0.038$ and $P=0.019$, respectively). Also, rs 2981578 AG genotype showed higher frequency of toxicities compared with GG genotype $(P<0.0001)$.

Conclusions: The results suggest these polymorphisms, especially rs1966265 and rs2981578, might be candidate pharmacogenomics factors to the response and prognosis prediction for individualized CET-based chemotherapy in breast cancer patients.
\end{abstract}

Keywords: Fibroblast growth factor receptors, rs1966265, rs2981578, Single-nucleotide polymorphism, Neoadjuvant chemotherapy, Breast cancer

\section{Background}

Breast cancer is a complex disease and the most common cancer in women worldwide with an estimated 1.7 million cases and 521,900 deaths in 2012 [1]. China, which has a massive population base, experienced the

\footnotetext{
*Correspondence: yeting_0525@hotmail.com; qyli1234@163.com

'Lu Chen and Huijie Qi contributed equally to this work.

${ }^{4}$ Nursing Department, Huashan Hospital, Fudan University, Shanghai, China

'Department of Pharmacy, Huashan Hospital, Fudan University, Shanghai,

China

Full list of author information is available at the end of the article
}

largest increase in incidence and mortality of breast cancer in recent years. Despite the recent progress in prevention, diagnosis, treatment of breast cancer and the consequent improvement in overall survival, the number of deaths increased $78 \%$ from 29,200 to 52,500 across entire age categories during 1990 to 2010 [2].

Presently, chemotherapy plays a crucial role in the systemic treatment of breast cancer. Yet, only 13\% patients benefit from chemotherapy in terms of prolonged overall survival, which implicates that individual genetic variation could be a significant factor for clinical

(C) The Author(s). 2018 Open Access This article is distributed under the terms of the Creative Commons Attribution 4.0 International License (http://creativecommons.org/licenses/by/4.0/), which permits unrestricted use, distribution, and 
responses [3]. Recently, numerous studies have demonstrated that single-nucleotide polymorphisms (SNPs) predict efficacy and toxicity of chemotherapy. Therefore, better predictive markers for improving personalized chemotherapy in breast cancer are urgently needed.

Fibroblast growth factor receptors (FGFRs) family, a sub family of receptor tyrosine kinases (RTKs), is comprised of four closely related genes (FGFR1-4) [4]. FGFR aberrations have been implicated in neoplastic human diseases and play important roles in tumor growth and progression [5]. FGFRs activating mutations and overexpression have been correlated with the development of various cancers, such as bladder, ovarian, breast, renal cell and squamous cell lung cancer [6]. The FGFRs are relevant to a broad spectrum of cellular processes in both embryonic and adult tissues. They induce diverse cellular responses beyond growth promoting signals in different target cells, such as human endothelial cells [7], pancreatic beta-cells [8], cancer cells [9-11] and vascular smooth muscle cells [12]. FGFR1 expression has been demonstrated to play imperative roles in mammary development and breast cancer tumourigenesis [13, 14]. Furthermore, amplification and overexpression of FGFR1 contributes to poor prognosis in luminal type breast cancers and serve as an independent predictor of poor outcome [15]. FGFR2 is a breast cancer susceptibility gene, and various variants of FGFR2 are significantly associated with the breast cancer risk [16]. Additionally, FGFR2 is essential in promoting breast tumorigenicity through self-renewal and maintenance of bipotent tumor-initiating cells [17]. FGFR3 could play an integral part in breast cancer development and be correlated with overall survival $[18,19]$. FGFR4 is highly expressed in a subset of breast cancer cells and primary tumors, suggesting the pivotal role in cell survival via activation of PI3K/AKT [20].

Identification of single-nucleotide polymorphisms (SNPs) predicting toxicity and/or efficacy of chemotherapy might be of great clinical value [21]. Previous studies have investigated associations between genetic variants in FGFR families and cancer risk. FGFR1 amplification is a common genetic event and associated with tumor growth and survival in squamous cell lung cancer [2224]. In addition, genetic variants of FGFR1 and FGFR2 may also be correlated not only with treatment toxicity but also with prognostic outcomes to cediranib therapy in nonsmall-cell lung cancer (NSCLC) [25]. Furthermore, the FGFR1 rs2288696 is the protective SNP with the highest statistical significance in ovarian cancer [26]. A present study has also investigated that FGFR1 rs2288696 may contribute to menarche timing in Ukrainian female, as well as early menarche onset is a known risk factor for breast and ovarian cancer in late adulthood [27]. As others have already shown, an intronic single nucleotide polymorphism in FGFR2 rs2981582 was identified as being associated with breast cancer risk. The risk appears to be consistent in either Han Chinese population or Caucasian, Mexican and Hispanic women [16]. Many studies have demonstrated that FGFR3 gene mutations were associated with many epithelial cancers, including colorectal cancer, bladder cancer, cervical carcinoma and nasopharyngeal carcinoma [28]. Additionally, a prospective Spanish study has identified the prevalence and prognostic significance of FGFR3 gene mutations in 772 superficial urothelial tumors. Furthermore, multivariate analysis of all the superficial tumors did establish that FGFR3 mutations were associated with an increased risk of recurrence [28]. A meta and pooled analyses provide evidence of a role for the FGFR4 Gly388Arg polymorphism in modulating patients' outcome in different types of cancer, thus offering to clinicians a new marker to predict predisposition to poor survival in cancer patients [29]. Moreover, the FGFR4 Arg388 allele may be closely interrelated with incidence of febrile neutropenia during neoadjuvant CET chemotherapy and is possibly useful as a patient related risk factor for febrile neutropenia [30].

Despite the well-known association between FGFR polymorphisms and the risk of breast cancer, few genetic variants of FGFR SNPs had been found to be associated with clinical outcomes in CET-based chemotherapy of breast cancer. To fill this gap, we selected eight SNPs of FGFRs which have been previously described to be associated with breast cancer risk [31], and evaluated the possible correlations between the SNPs and the efficacy/ toxicity of CET-based chemotherapy in patients with Chinese breast cancer.

\section{Methods}

\section{Study population and chemotherapy}

A total of 211 women with histologically proven invasive breast carcinoma were recruited to this study. These patients underwent surgery in the Department of Breast Disease at Shanghai Huashan Hospital (Shanghai, China) between September 2015 and November 2016. Every patient received CET-based chemotherapy. Of all the patients, 120 received adjuvant chemotherapy (ACT) and 91 received neoadjuvant chemotherapy (NCT). Patients received CET (cyclophosphamide $600 \mathrm{mg} / \mathrm{m}^{2}$ i.v. in $1 \mathrm{~h}$, epirubicin $75 \mathrm{mg} / \mathrm{m}^{2}$ i.v. in $15 \mathrm{~min}$ and docetaxel $75 \mathrm{mg} / \mathrm{m}^{2}$ i.v. in $1 \mathrm{~h}$ ) on the first day of each of four 21-day cycles chemotherapy. All patients filled the informed consent forms and agreed to have their samples used for research purposes. The procedures of this study were approved by the Huashan Hospital Institutional Review Board and the approved number of ethic committee was 2017-017. 


\section{Response and toxicity evaluation criteria}

The effect of FGFR gene polymorphisms on the response was evaluated in patients (90) receiving only CET-based NCT, whereas that on toxicities was evaluated in patients (211) receiving both CET-based NCT (90) and ACT (120). Tumor response to chemotherapy was assessed after the first two or three cycles NCT and determined by the Response Evaluation Criteria in Solid Tumors (RECIST) criteria [32]. For data analysis, patients were categorized into two groups as responders (complete + partial response) and non-responders (stable + progressive disease). Toxicities were graded according to the National Cancer Common Terminology Criteria for Adverse Events (CTCAE v4.0) [33]. TNM stages were determined according to the 8th American Joint Committee on Cancer (AJCC) TNM system.

\section{DNA samples}

A peripheral blood sample from each patient was collected. Peripheral blood samples were centrifuged at $3000 \mathrm{rpm} / \mathrm{min}$ for $10 \mathrm{mins}$ and then the blood serum was separated out. Genomic DNA was extracted after red cell lysis and isolated from peripheral blood leukocytes using erythrocyte lysate of TIAamp ${ }^{\circ}$ Blood DNA Kit (Tiangen, Beijing, China).

\section{Clinicopathological factors}

The expression of ER and PR was detected using immunohistochemistry methods and scored according to the Allred system [34]. HER2 positivity was defined as $3+$ staining in immunohistochemistry or unequivocal HER2 gene amplification by fluorescent in situ hybridization (FISH). Immunohistochemistry for P63 expression was realised to be negative if positive staining was detected in less than $5 \%$ of all the cells [35]. The optimal cut-off to classified the status of $\mathrm{Ki} 67$ was defined as $20 \%$ (i.e. $\geq$ $20 \%$ staining was defined as Ki67hi), according to the 2015 recommendations [36].

\section{SNP selection and genotyping}

We selected 8 SNPs of the FGFR1-4 genes according to the following criteria: 1) the minor allele frequencies (MAF) of these SNPs were greater than 10\%, 2) SNPs have been associated with breast cancer risk or clinical outcome in prior studies. The details of the genetic variants studies, minor allele frequency (MAF) and primer sequences are summarized in Table 1. Eight single nucleotide polymorphisms was determined using the TaqMan Pre-Designed SNP Genotyping Assays (Applied Biosystems, Foster City, CA) following manufacturer's instructions. Polymerase chain reaction (PCR) was performed in a final volume of $5-\mu$ l containing TaqMan Universal PCR Master Mix, TaqMan SNP Genotyping Assays Mix, and $20 \mathrm{ng}$ of genomic DNA. PCR products were sequenced using an ABI Prism ${ }^{\circ} 3730$ DNA Analyzer (Applied Biosystems, Foster City, CA) and data were collected using GeneMapper ${ }^{\circledR}$ version 4.0 software (Applied Biosystems, Foster City, CA).

\section{Statistical analysis}

The primary end point of the study was to analyze the association between the genetic polymorphisms and clinical outcome and toxicity. Chi-square $\left(x^{2}\right)$ test for categorical variables was used to estimate population distribution characteristics and compare the differences in the genotype frequencies between patients with different treatment outcomes and toxicity. Meanwhile, chi-square $\left(\chi^{2}\right)$ test was also used to analyze associations between an individual SNP and clinicopathological parametrs. Odd ratios (ORs) with 95\% confidence intervals

Table 1 Information for the SNPs genotyped in this study

\begin{tabular}{|c|c|c|c|c|}
\hline Gene & Ref SNP ID & Alleles & MAF & Primer sequences \\
\hline FGFR1 & rs2288696 & $C / T$ & 0.14 & $\begin{array}{l}\text { 5'-GGTGCCCTATCTGCTCTG-3', } \\
\text { 5'-CTTGGTGGGATGGAAACT-3' }\end{array}$ \\
\hline \multirow[t]{5}{*}{ FGFR2 } & rs2981582 & $\mathrm{C} / \mathrm{T}$ & 0.40 & $\begin{array}{l}\text { 5'-TCTGTCATCAGTAGGGAATA-3', } \\
\text { 5'-ATCACCAAGAGGCAGTTC-3' }\end{array}$ \\
\hline & rs1219648 & $A / G$ & 0.41 & $\begin{array}{l}\text { 5'-ACATCCCTTGTTCTCGTT-3', } \\
\text { 5'-ATTGCCTTGGCTATTCAG-3' }\end{array}$ \\
\hline & rs2420946 & T/C & 0.44 & $\begin{array}{l}\text { 5'-TTTGGTGGAAGAGTCAGA-3', } \\
\text { 5'-GTCCCAGAGGATTTGTTT-3' }\end{array}$ \\
\hline & rs2981579 & $\mathrm{T} / \mathrm{C}$ & 0.49 & $\begin{array}{l}\text { 5'-TGTGACTCCCTTCATCGT-3', } \\
\text { 5'-TGGTCTATTTCTCAATCCCTA-3' }\end{array}$ \\
\hline & rs2981578 & $\mathrm{G} / \mathrm{A}$ & 0.37 & $\begin{array}{l}\text { 5'-CTGCTTTGGAGGATTGTGA-3', } \\
\text { 5'-GAGACTGGGAAACAGATGGT-3' }\end{array}$ \\
\hline FGFR3 & rs743682 & $\mathrm{G} / \mathrm{A}$ & 0.17 & $\begin{array}{l}\text { 5'-TACAAAGACCTCGTGAAATGG-3', } \\
\text { 5'-CAAATCCAGACTCGCTTCC-3' }\end{array}$ \\
\hline FGFR4 & rs1966265 & $\mathrm{G} / \mathrm{A}$ & 0.23 & $\begin{array}{l}\text { 5'-GCCGCCTTGTCAGTTGTG-3', } \\
\text { 5'-TCCTGGTGCCCACTCTTCC-3' }\end{array}$ \\
\hline
\end{tabular}

SNP single nucleotide polymorphism, MAF minor allele frequency 
(95\%CIs) were calculated by unconditional logistic regression to analyze the associations between genetic polymorphisms and clinical outcome and toxicity. ORs with 95\%CIs were adjusted for confounding variables like age, menstrual status, clinical TNM stage, histology, tumor grade, HER2 status and hormone receptor (HR). $P$-value $<0.05$ was considered to be statistically significant, while $P<0.100$ was treated as an indicator for trend in given analysis. All statistical analyses were conducted using the SPSS version 16.0 for Windows (SPSS, Chicago, IL, USA). The Hardy-Weinberg equilibrium (HWE) was examined in patients (211) receiving both CET-based NCT (90) and ACT (120) by using the chi-squared test.

\section{Results}

Patient characteristics and clinical predictors

The discovery cohort included 211 patients who received 4 cycles of anthracycline-based CET regimen. The demographic and clinical characteristics of patients in study were listed in Table 2. The clinicopathological characteristics and the association with chemotherapy treatment response and toxicity are presented in Table 3. According to the RECIST criteria, response assessment was made in 90 patients who were given NCT, and it was observed that 29 (32\%) patients were responders and $61(68 \%)$ patients were non-responders. Then, toxicity was assessed in 211 patients who were given NCT and ACT according to the CTCAE. Among them, 112 (48\%) patients suffered from grade 3-4 toxicity while 109 (52\%) patients had no grade 3-4 toxicity. As shown in Table 3, patients who responded to NCT were comparable to those who did not respond in terms of age, menstrual status, tumor status, lymph node status, tumor grade, HR status, triple-negative breast cancer (TNBC), P63, Ki67, and Her-2/neu expression $(P>0.05)$. Similarly, patients who suffered from grade 3-4 toxicity did not differ significantly with those no or grade 1-2 toxicity in terms of age, menstrual status, lymph node

Table 2 Patient characteristics $(N=211)$

\begin{tabular}{llr}
\hline & Mean \pm SD & $N(\%)$ \\
\hline Age at diagnosis (years) & $54.278 \pm 10.163$ & \\
$\begin{array}{l}\text { Menopausal state } \\
\quad \text { premenopausal }\end{array}$ & $63(29.9)$ \\
$\quad$ postmenopausal & & $148(70.1)$ \\
Age at postmenopause (years) & $52.367 \pm 8.132$ & \\
Height (cm) & $159.672 \pm 5.369$ & \\
Weight (kg) & $62.483 \pm 8.859$ & \\
BMl (kg.m ${ }^{-2}$ ) & $24.114 \pm 3.156$ & $194(91.9)$ \\
Parity & & \\
\hline
\end{tabular}

BMI body mass index status, tumor grade, HR status, TNBC, P63, Ki67, and Her-2/neu expression $(P>0.05)$. However, patients who suffered from grade 3-4 toxicity varied significantly in terms of tumor status (Table $3, P<0.001$ ).

\section{Associations between SNPs and clinical outcomes}

Considering the potential of FGFR gene polymorphisms to predict therapy response, we distributed the relationship between 8 selected SNPs of FGFR and the efficacy of chemotherapy in Table 4. The results of unconditional logistic regression analysis revealed that the genotype distribution of the FGFR4 rs1966265 polymorphisms was significantly different between the responders and non-responders. For rs1966265, AA genotype had significant correlation with the clinical response to NCT when compared with GG genotype (adjusted $\mathrm{OR}=0.17$, 95\% $\mathrm{CI}=0.03-0.74, P=0.019$ ). Furthermore, a significant correlation was observed in the recessive model (AA vs. AG/GG: adjusted $\mathrm{OR}=1.33,95 \% \mathrm{CI}=1.88$ $25.19, P=0.004)$. Moreover, the individual carrying A allele had significantly rates of response to NCT when compared to those carrying $\mathrm{G}$ allele (A vs. G: adjusted $\mathrm{OR}=0.43,95 \% \mathrm{CI}=0.23-0.81, P=0.009$ ).

For FGFR2 rs2981578, the individual carrying A allele had significant rates of response when compared with those carrying $\mathrm{G}$ allele (A vs. G: adjusted $\mathrm{OR}=2.10,95 \%$ $\mathrm{CI}=1.10-4.03, \quad P=0.025)$. However, no significant associations were observed between the other six SNPs examined and the response to neoadjuvant CET chemotherapy (Table 4).

\section{Correlation between FGFR SNP $\mathrm{s}$ and adverse events}

Having confirming that FGFR SNPs (rs1966265 and rs2981578) were associated with clinical response, we further investigated the potential association between FGFR SNPs and clinical toxicities. As shown in Table 5, toxicities of 211 studied patients according to the NCI-CTCAE version 4.0 are summarized. Overall, grade 3-4 toxicities were observed in 102 patients (48\%). Grade 3-4 leucopenia developed in 95 (93.1\%) patients with $90(88.2 \%)$ neutropenia, as grade $3-4$ vomiting did in 18 patients $(17.4 \%)$. No treatment related mortality was encountered in the study.

Next, we analyzed the association between toxicity outcomes and FGFR SNPs (Table 6). The results of unconditional logistic regression analysis demonstrated that CC genotype of FGFR1 rs2420946 was associated with higher frequency of toxicities compared with TT genotype (adjusted $\mathrm{OR}=2.35,95 \% \mathrm{CI}=1.05-5.28$, $P=0.038)$. The relevance of $\mathrm{rs} 2420946$ with total toxicity in recessive model was (CC vs. CT/TT: adjusted $\mathrm{OR}=0.51,95 \% \mathrm{CI}=0.29-0.90, P=0.019$ ). All the results show that individuals with the $C$ allele of FGFR1 rs2420946 presented a greater risk of overall 
Table 3 The clinic-pathological parameters among patients with different treatment response and toxicity

\begin{tabular}{|c|c|c|c|c|c|c|}
\hline \multirow[t]{2}{*}{ Characteristic } & \multicolumn{2}{|c|}{ Response to chemotherapy $(N=90)$} & \multicolumn{4}{|c|}{ Toxicity to chemotherapy $(N=211)$} \\
\hline & Response $(N=29)$ & Non-response $(N=61)$ & $p$ & Toxicity $(N=102)$ & No toxicity $(N=109)$ & $P$ \\
\hline \multicolumn{2}{|c|}{ Age in years(mean $\pm S D)$} & & 0.539 & & & 0.195 \\
\hline$\leq 45$ & $4(13.8)$ & $10(16.4)$ & & 17(16.7) & $22(20.2)$ & \\
\hline $46-55$ & 10(34.5) & $27(44.3)$ & & $39(38.2)$ & $29(26.6)$ & \\
\hline$>55$ & $15(51.7)$ & 24(39.3) & & $46(45.1)$ & $58(53.2)$ & \\
\hline \multicolumn{2}{|l|}{ Menstrual status } & & 0.516 & & & 0.891 \\
\hline Premenopausal & $8(27.6)$ & $21(34.4)$ & & $30(29.4)$ & $33(30.3)$ & \\
\hline Postmenopausal & $21(72.4)$ & $40(65.6)$ & & 72(70.6) & $76(69.7)$ & \\
\hline \multicolumn{2}{|l|}{ T-status,n(\%) } & & 0.250 & & & $<0.001^{*}$ \\
\hline $\mathrm{T} 1$ & / & / & & / & / & \\
\hline $\mathrm{T} 2$ & $1(3.4)$ & $5(8.2)$ & & $17(16.7)$ & $74(67.9)$ & \\
\hline T3 & 27(93.1) & $56(91.8)$ & & $84(82.4)$ & $32(29.4)$ & \\
\hline T4 & $1(3.4)$ & $0(0)$ & & $1(1.0)$ & $3(2.8)$ & \\
\hline \multicolumn{2}{|l|}{ N-status,n(\%) } & & 0.209 & & & 0.168 \\
\hline No & $7(24.1)$ & $27(44.3)$ & & 38(37.3) & 27(24.8) & \\
\hline N1 & $13(44.8)$ & 23(37.7) & & 40(39.2) & $58(53.2)$ & \\
\hline N2 & $6(20.7)$ & $9(14.8)$ & & 18(17.6) & 19(17.4) & \\
\hline N3 & $3(10.3)$ & 2(3.3) & & $6(5.9)$ & $5(4.6)$ & \\
\hline \multicolumn{2}{|l|}{ Tumor grade } & & 0.066 & & & 0.078 \\
\hline Grade I & / & / & & / & / & \\
\hline Grade II & $7(24.1)$ & $27(44.3)$ & & $41(40.2)$ & $57(52.3)$ & \\
\hline Grade III & $22(75.9)$ & $34(55.7)$ & & 61(59.8) & $52(47.7)$ & \\
\hline \multicolumn{2}{|l|}{ ER status } & & 0.050 & & & 0.650 \\
\hline Positive & $24(82.8)$ & $38(62.3)$ & & 72(70.6) & $80(73.4)$ & \\
\hline Negative & $5(17.2)$ & $23(37.7)$ & & $30(29.4)$ & 29(26.6) & \\
\hline \multicolumn{2}{|l|}{ PR status } & & 0.476 & & & 0.995 \\
\hline Positive & $24(82.8)$ & $38(62.3)$ & & 59(57.8) & $63(57.8)$ & \\
\hline Negative & $5(17.2)$ & 23(37.7) & & $43(42.2)$ & $46(42.2)$ & \\
\hline \multicolumn{2}{|l|}{ Her2 status } & & 0.883 & & & 0.525 \\
\hline Positive & $10(34.5)$ & $22(36.1)$ & & $35(34.3)$ & $42(38.5)$ & \\
\hline Negative & 19(65.5) & $39(63.9)$ & & $67(65.7)$ & $67(61.5)$ & \\
\hline \multicolumn{2}{|l|}{ TNBC } & & 0.618 & & & 0.428 \\
\hline yes & 2(6.9) & 15(24.6) & & 16(15.7) & 13(11.9) & \\
\hline no & 27(93.1) & $46(75.4)$ & & $86(84.3)$ & $96(88.1)$ & \\
\hline \multicolumn{2}{|l|}{ P63 } & & 0.967 & & & 0.281 \\
\hline positive & $1(3.4)$ & $2(3.3)$ & & $3(2.9)$ & $1(0.9)$ & \\
\hline negative & 28(96.6) & 59(96.7) & & & & \\
\hline \multicolumn{2}{|l|}{ Ki-67 } & & 0.324 & 17(16.7) & $22(20.2)$ & 0.195 \\
\hline$<20 \%$ & $7(24.1)$ & 21(34.4) & & $39(38.2)$ & 29(26.6) & \\
\hline$\geq 20 \%$ & $22(75.9)$ & $40(65.6)$ & & $46(45.1)$ & $58(53.2)$ & \\
\hline
\end{tabular}

$T$ tumor stage, $N$ nodes stage, $T N B C$ triple negative breast cancer, Her 2 human epidermal growth factor receptor $2 ;{ }^{*}$ A $P$ value $<0.05$ was considered ststistically significant

toxicity for CET chemotherapy in breast cancer (ad- associated with higher frequency of toxicities comjusted $\mathrm{OR}=1.65, \quad 95 \% \mathrm{CI}=1.11-2.46, \quad P=0.013$ ). $\quad$ pared with $\mathrm{GG}$ genotype (adjusted $\mathrm{OR}=4.91,95 \%$ Meanwhile, for FGFR2 rs2981578, AG genotype was $\mathrm{CI}=2.65-9.08, \quad P<0.0001)$. The correlation of 
Table 4 Univariate analyses of the associations between FGFR polymorphisms and the response of neoadjuvant chemotherapy

\begin{tabular}{|c|c|c|c|c|c|c|}
\hline Target Gene & Polymorphisms/Genotype & $\begin{array}{l}\text { Nonresponders } \\
N=29(32 \%)\end{array}$ & $\begin{array}{l}\text { Responders } \\
N=61(68 \%)\end{array}$ & OR $(95 \% \mathrm{Cl})$ & $P$ & $P_{H W E}$ \\
\hline \multirow[t]{9}{*}{ FGFR1 } & rs2288696 & & & & & 0.014 \\
\hline & $\mathrm{C} / \mathrm{C}$ & 25(86.2) & $50(82.0)$ & Reference & 1.000 & \\
\hline & $C / T$ & $1(3.4)$ & 11(18.0) & $1.00(0.28-3.64)$ & 0.999 & \\
\hline & $T / T$ & $3(10.3)$ & $0(0)$ & 0 & 0.615 & \\
\hline & Dominat model & $4(13.8)$ & $4(6.6)$ & $0.73(0.21-2.52)$ & & \\
\hline & Recessive model & 26(89.7) & $61(100)$ & 0 & 1.000 & \\
\hline & Alleles & & & & & \\
\hline & C & $51(87.9)$ & $111(91.0)$ & Reference & 0.344 & \\
\hline & T & $7(12.1)$ & $11(9.0)$ & $0.57(0.18-1.82)$ & 0.999 & \\
\hline \multirow[t]{34}{*}{ FGFR2 } & rs2981582 & & & & & 0.343 \\
\hline & $\mathrm{C} / \mathrm{C}$ & $11(37.9)$ & $31(50.8)$ & Reference & & \\
\hline & $C / T$ & $15(51.7)$ & $21(34.4)$ & $2.01(0.78-5.23)$ & 0.151 & \\
\hline & $T / T$ & $3(10.3)$ & $9(14.8)$ & $0.94(0.22-4.11)$ & 0.934 & \\
\hline & Dominat model & 18(62.1) & $30(49.2)$ & $1.69(0.69-4.17)$ & 0.254 & \\
\hline & Recessive model & $26(89.7)$ & $52(85.2)$ & $1.50(0.37-6.02)$ & 0.567 & \\
\hline & Alleles & & & & & \\
\hline & C & $37(63.8)$ & $83(68.0)$ & Reference & & \\
\hline & T & $21(36.2)$ & 39(32.0) & $1.21(0.63-2.33)$ & 0.573 & \\
\hline & rs1219648 & & & & & 0.700 \\
\hline & $A / A$ & $9(31.0)$ & 19(31.1) & Reference & & \\
\hline & $\mathrm{A} / \mathrm{G}$ & $16(55.2)$ & $30(49.2)$ & $1.13(0.42-3.06)$ & 0.816 & \\
\hline & $\mathrm{G} / \mathrm{G}$ & $4(13.8)$ & $12(19.7)$ & $0.70(0.18-2.80)$ & 0.618 & \\
\hline & Dominat model & $20(69.0)$ & $42(68.9)$ & $1.01(0.39-2.61)$ & 0.99 & \\
\hline & Recessive model & $25(86.2)$ & 49(80.3) & $1.53(0.45-5.24)$ & 0.498 & \\
\hline & Alleles & & & & & \\
\hline & A & 34(58.6) & $68(55.7)$ & Reference & & \\
\hline & G & $24(41.4)$ & $54(44.3)$ & $0.89(0.47-1.67)$ & 0.715 & \\
\hline & rs2420946 & & & & & 0.377 \\
\hline & $\mathrm{T} / \mathrm{T}$ & $1(3.4)$ & 11(18.0) & Reference & & \\
\hline & $C / T$ & $18(62.1)$ & $29(47.5)$ & $6.83(0.81-57.45)$ & 0.077 & \\
\hline & $\mathrm{C} / \mathrm{C}$ & $10(34.5)$ & $21(34.4)$ & $5.24(0.59-46.40)$ & 0.137 & \\
\hline & Dominat model & 28(96.6) & $50(82.0)$ & $6.16(0.76-50.24)$ & 0.090 & \\
\hline & Recessive model & $22(75.9)$ & $54(88.5)$ & $1.00(0.39-2.53)$ & 0.996 & \\
\hline & Alleles & & & & & \\
\hline & T & $20(34.5)$ & $51(41.8)$ & Reference & & \\
\hline & $C$ & $38(65.5)$ & $71(58.2)$ & $1.37(0.71-2.61)$ & 0.348 & \\
\hline & rs2981579 & & & & & 0.060 \\
\hline & $T / T$ & $7(24.1)$ & $18(29.5)$ & Reference & & \\
\hline & $C / T$ & $12(41.4)$ & 24(39.3) & $1.29(0.42-3.92)$ & 0.659 & \\
\hline & $\mathrm{C} / \mathrm{C}$ & $10(34.5)$ & 19(31.1) & $1.35(0.42-4.32)$ & 0.610 & \\
\hline & Dominat model & $22(75.9)$ & $43(70.5)$ & $2.39(0.96-5.99)$ & 0.062 & \\
\hline & Recessive model & 26(89.7) & 51() & $0.86(0.34-2.20)$ & 0.752 & \\
\hline & Alleles & & & & & \\
\hline
\end{tabular}


Table 4 Univariate analyses of the associations between FGFR polymorphisms and the response of neoadjuvant chemotherapy (Continued)

\begin{tabular}{|c|c|c|c|c|c|c|}
\hline Target Gene & Polymorphisms/Genotype & $\begin{array}{l}\text { Nonresponders } \\
N=29(32 \%)\end{array}$ & $\begin{array}{l}\text { Responders } \\
N=61(68 \%)\end{array}$ & OR $(95 \% \mathrm{Cl})$ & $P$ & $P_{H W E}$ \\
\hline & T & $26(44.8)$ & $60(49.2)$ & Reference & & \\
\hline & $C$ & $32(55.2)$ & $62(50.8)$ & $1.19(0.64-2.23)$ & 0.585 & \\
\hline & rs2981578 & & & & & 0.060 \\
\hline & $\mathrm{G} / \mathrm{G}$ & $10(34.5)$ & $34(55.7)$ & Reference & & \\
\hline & $A / G$ & $12(41.4)$ & $20(32.8)$ & $2.04(0.75-5.57)$ & 0.164 & \\
\hline & $A / A$ & $7(24.1)$ & $7(11.5)$ & $3.40(0.96-12.02)$ & 0.058 & \\
\hline & Dominat model & $19(65.5)$ & $27(44.3)$ & $2.39(0.96-5.99)$ & 0.062 & \\
\hline & Recessive model & $22(75.9)$ & $54(88.5)$ & $0.41(0.13-1.30)$ & 0.129 & \\
\hline & Alleles & & & & & \\
\hline & G & $32(55.2)$ & $88(72.1)$ & Reference & & \\
\hline & A & $26(44.8)$ & $34(27.9)$ & $2.10(1.10-4.03)$ & $0.025^{*}$ & \\
\hline \multirow[t]{9}{*}{ FGFR3 } & rs743682 & & & & & 0.198 \\
\hline & $\mathrm{G} / \mathrm{G}$ & $25(86.2)$ & $49(80.3)$ & Reference & & \\
\hline & $A / G$ & $3(10.3)$ & 11(18.0) & $0.54(0.14-2.09)$ & 0.368 & \\
\hline & $A / A$ & $1(3.4)$ & $1(1.6)$ & $1.96(0.12-32.67)$ & 0.639 & \\
\hline & Dominat model & $4(13.8)$ & $12(19.7)$ & $0.65(0.65-0.19)$ & 0.498 & \\
\hline & Recessive model & 27(93.1) & $61(100)$ & $0.47(0.03-7.74)$ & 0.595 & \\
\hline & Alleles & & & & & \\
\hline & G & 53(91.4) & 109(89.3) & Reference & & \\
\hline & A & $5(8.6)$ & 13(10.7) & $0.79(0.27-2.34)$ & 0.671 & \\
\hline \multirow[t]{9}{*}{ FGFR4 } & rs1966265 & & & & & 0.343 \\
\hline & $\mathrm{G} / \mathrm{G}$ & $8(27.6)$ & $12(19.7)$ & Reference & & \\
\hline & $A / G$ & $18(62.1)$ & $22(36.1)$ & $1.23(0.41-3.65)$ & 0.713 & \\
\hline & $A / A$ & $3(10.3)$ & $27(44.3)$ & $0.17(0.04-0.74)$ & $0.019^{*}$ & \\
\hline & Dominat model & $21(72.4)$ & 49(80.3) & $1.16(0.64-1.80)$ & 0.401 & \\
\hline & Recessive model & 26(89.7) & $34(55.7)$ & $6.88(1.88-25.2)$ & $0.004^{*}$ & \\
\hline & Alleles & & & & & \\
\hline & G & $34(58.6)$ & $46(37.7)$ & Reference & & \\
\hline & A & 24(41.4) & $76(62.3)$ & $0.43(0.23-0.81)$ & $0.009^{*}$ & \\
\hline
\end{tabular}

OR odds ratio, $95 \% \mathrm{Cl} 95 \%$ confidence interval, * A $P$ value $<0.05$ was considered ststistically significant

rs2981578 with total toxicity in dominant model was (GG vs. AG/AA: adjusted $\mathrm{OR}=2.57,95 \% \mathrm{CI}=0.99-$ $6.69, P<0.0001)$. All the results show that individuals with the A allele of FGFR2 rs2981578 presented a greater risk of overall toxicity for CET chemotherapy in breast cancer (adjusted $\mathrm{OR}=2.37,95 \% \mathrm{CI}=1.55-3.61$, $P<0.0001)$.

\section{Association between rs1966265 and clinicopathologic variables}

Based on the striking observation that rs1966265 might serve as an independent predictive factor for clinical response to $\mathrm{NCT}$ with $\mathrm{CET}$ regimen, we performed an exploratory analysis to investigate the correlation between rs1966265 and clinicopathologic variables. With respect to other important clinicopathological factors in breast cancer such as grading, HR status, Her2/neu status, and age, however, no statistically significant correlations were observed. The associations between FGFR4 genotype and clinicopathological prognostic factors are summarized in Table 7.

\section{Discussion}

The principal finding of this trial is that two SNPs (rs1966265 and rs2981578) contribute to clinical outcome of breast cancer treated with CET-based chemotherapy. In addition, our results showed for the first time that rs2420946 CC genotype and rs2981578 
Table 5 drug toxicity and adverse events

\begin{tabular}{lll}
\hline Adverse events & $\begin{array}{l}\text { No toxicity (grade0-2) } \\
(N=109)\end{array}$ & $\begin{array}{l}\text { Toxicity(grade 3-4) } \\
(N=102)\end{array}$ \\
\hline Hematological & 98 & 95 \\
Leucopenia & 93 & 90 \\
Neutropenia & 8 & 1 \\
Anemia & 2 & 1 \\
Thrombocytopenia & & \\
Gastrointestinal & 47 & 0 \\
Nausea & 86 & 18 \\
Vomiting & 16 & 13 \\
Diarrhea & 6 & 2 \\
Skin rash & 3 & 0 \\
hepatotoxicity & 1 & 0 \\
Renal toxicity & &
\end{tabular}

GG genotype demonstrated the association with chemotherapy toxicities. Given the critical role of FGFR genetic variations in breast cancer, these polymorphisms, especially rs1966265 and rs2981578, might be vital response and prognostic indicators for breast cancer.

It is generally known that the development and progression of breast cancer is a complicated process that involves both epigenetic and genetic factors [37]. Randomized trials [38] have proved the neoadjuvant chemotherapy (NCT) is the standard of care for patients with inflammatory and inoperable breast cancer, which has been a widely accepted modality for treatment of early breast cancer. In addition to decreasing relapse and mortality of tumor, neoadjuvant chemotherapy is also effective with respect to enhancing disease-free and overall survival $[38,39]$. Furthermore, for the reason that NCT offers the unique opportunity to directly measure a tumour's response to therapy, it is one of the best way to evaluate new predictive and prognostic factors in breast cancer [40]. Practice has proven that anthracyclines doxorubicin (DOXO) or epirubicin (EPI) and taxanes $(\mathrm{T})$ are among the most effective cytotoxic treatments developed for the comprehensive treatment of breast cancer. Meanwhile, variability in quality-of-life impairing toxicity or life-threaten side effects remain a major problem for patients with neoadjuvant chemotherapy. With some patients' poor response to chemotherapy, suspectable to toxicity of chemotherapy, better predictive markers for NCT are urgently needed.

SNPs in genes involving pharmacokinetics such as drug metabolism and drug efflux transporters can modulate the metabolism and distribution of drugs and therefore influence response to chemotherapy. Nowadays, a growing number of research has indicated that other genes involving the occurrence and development of tumor are also connected with chemotherapy outcomes and toxicities. More recently, accumulating evidence indicates that FGFs and FGFRs may promote cancer progression by inducing mitogenic and survival signals, as well as epithelial-mesenchymal transition invasion and tumor angiogenesis [41, 42]. FGFR alterations are detected in a variety of human cancers, such as prostate, bladder, breast, lung and endometrial cancers. Furthermore, the correlations of FGFR family genetic variations with the susceptibility and clinicopathological features of cancer patients have been intensely investigated. Nevertheless, little is known about the associations between FGFR SNPs and the clinical outcomes of breast cancer patients after CET regimen.

Thereafter, the present study firstly evaluated the effect of eight selected potentially functional SNPs of FGFR on chemotherapy efficacy of CET in breast cancer patients. The major finding was a significant association of FGFR4 rs1966265 AA genotype and A allele and FGFR2 rs2981578 A alleles with an increased chemosensitivity in NCT of breast cancer patients. The Chi-square test has showed no deviation from Hardy Weinberg equilibrium for the two SNPs in patients (211) receiving both CET-based NCT (90) and ACT (120), suggesting that the association does not result from population admixture or genotyping errors.

Our finding that FGFR4 rs1966265 polymorphism predicted the individual clinical response to the CET regimen is in accordance with the results from a previous study [42]. In the susceptibility analysis of breast cancer, for rs1966265, Jiang et al. demonstrated that the AG and GG genotypes conferred a significantly increased risk for breast cancer compared to the AA genotype in the dominant model $(\mathrm{OR}=1.66,95 \% \mathrm{CI}=$ 1.31-2.11, $P<0.001$ ) [42]. Several other studies have also investigated the possible relationship between the rs1966265 polymorphism and disease risk. Chen et al. [43] demonstrated that FGFR4 rs1966265 was associated with the progression of cervical normal tissues to precancerous lesions in Asian women. Rezvani et al. [44] showed rs1966265 in FGFR4 is a possible genetic key variant in respiratory distress syndrome $(P=0.003)$ and colonic transit $(P=0.043)$, respectively [45]. Camilleri et al. revealed that FGFR4 rs1966265 was associated with stool level of bile acid (BA) $(P=0.032)$ [46]. Taken together, our results presented here suggested that FGFR4 rs1966265 polymorphisms could be employed as a biomarker for the prediction of clinical outcomes of CET-based chemotherapy in breast cancer patients.

Nevertheless, it is worthy to note that rs1966265 (Val 10 Ile) is a missense variant in FGFR4. In another investigation focused on FGFR4 missense variant, the GG of FGFR4 rs351855 (Gly 388 Arg) showed significantly better overall survival than the AG or AA among 273 colon cancer patients, regardless of adjuvant 
Table 6 Genotypes of 8 SNPs of FGFR gene and their associations with adverse events

\begin{tabular}{|c|c|c|c|c|c|c|}
\hline Target Gene & Polymorphisms/Genotype & $\begin{array}{l}\text { Toxicity(grade 3-4) } \\
N=102(48 \%)\end{array}$ & $\begin{array}{l}\text { No toxicity (grade1-2) } \\
N=109(52 \%)\end{array}$ & OR $(95 \% \mathrm{Cl})$ & $P$ & $P_{\text {HWE }}$ \\
\hline \multirow[t]{9}{*}{ FGFR1 } & rs2288696 & & & & & 0.035 \\
\hline & $\mathrm{C} / \mathrm{C}$ & $85(83.3 \%)$ & $88(80.7 \%)$ & Reference & & \\
\hline & $C / T$ & 14(13.7\%) & 19(17.4\%) & $0.76(0.36-1.62)$ & 0.480 & \\
\hline & $\mathrm{T} / \mathrm{T}$ & $3(2.9 \%)$ & $2(1.8 \%)$ & $1.55(0.25-9.53)$ & 0.634 & \\
\hline & Dominat model & $17(16.7 \%)$ & $21(19.3 \%)$ & $0.84(0.41-1.70)$ & 0.624 & \\
\hline & Recessive model & 99(97.1\%) & 107(98.2\%) & $0.62(0.10-3.77)$ & 0.601 & \\
\hline & Alleles & & & & & \\
\hline & C & 184(90.2\%) & 195(89.4\%) & Reference & & \\
\hline & $\mathrm{T}$ & $20(9.8 \%)$ & $23(10.6 \%)$ & $0.92(0.49-1.73)$ & 0.800 & \\
\hline \multirow[t]{34}{*}{ FGFR2 } & rs2981582 & & & & & 0.138 \\
\hline & $\mathrm{C} / \mathrm{C}$ & $52(51.0 \%)$ & $47(43.1 \%)$ & Reference & & \\
\hline & $C / T$ & $37(36.3 \%)$ & $47(43.1 \%)$ & $0.71(0.40-1.28)$ & 0.253 & \\
\hline & $\mathrm{T} / \mathrm{T}$ & $13(12.7 \%)$ & $15(13.8 \%)$ & $0.78(0.34-1.82)$ & 0.569 & \\
\hline & Dominat model & $50(49.0 \%)$ & $62(56.9 \%)$ & $0.73(0.42-1.25)$ & 0.253 & \\
\hline & Recessive model & $89(87.3 \%)$ & $94(86.2 \%)$ & $1.09(0.49-2.43)$ & 0.828 & \\
\hline & Alleles & & & & & \\
\hline & C & $141(69.1 \%)$ & $141(64.7 \%)$ & Reference & & \\
\hline & $\mathrm{T}$ & 63(30.9\%) & $77(35.3 \%)$ & $0.82(0.55-1.30)$ & 0.333 & \\
\hline & rs1219648 & & & & & 0.726 \\
\hline & $\mathrm{A} / \mathrm{A}$ & $34(33.3 \%)$ & $33(30.3 \%)$ & Reference & & \\
\hline & $A / G$ & 49(48.0\%) & $57(52.3 \%)$ & $0.83(0.45-1.54)$ & 0.562 & \\
\hline & $\mathrm{G} / \mathrm{G}$ & 19(18.6\%) & 19(17.4\%) & $0.97(0.44-2.15)$ & 0.941 & \\
\hline & Dominat model & $68(66.7 \%)$ & $76(69.7 \%)$ & $0.87(0.49-1.55)$ & 0.634 & \\
\hline & Recessive model & 83(81.4\%) & $90(82.6 \%)$ & $0.92(0.46-1.86)$ & 0.821 & \\
\hline & Alleles & & & & & \\
\hline & $A$ & $117(57.4 \%)$ & $123(56.4 \%)$ & Reference & & \\
\hline & G & $87(42.6 \%)$ & $95(43.6 \%)$ & $0.96(0.66-1.42)$ & 0.847 & \\
\hline & rs2420946 & & & & & 0.172 \\
\hline & $\mathrm{T} / \mathrm{T}$ & 13(12.7\%) & $22(20.2 \%)$ & Reference & & \\
\hline & $C / T$ & 39(38.2\%) & $51(46.8 \%)$ & $1.29(0.58-2.89)$ & 0.529 & \\
\hline & $C / C$ & $50(49.0 \%)$ & $36(33.0 \%)$ & $2.35(1.05-5.28)$ & $0.038^{*}$ & \\
\hline & Dominat model & 89(87.3\%) & 87(79.8\%) & $1.73(0.82-3.65)$ & 0.150 & \\
\hline & Recessive model & $52(51.0 \%)$ & $73(67.0 \%)$ & $0.51(0.29-0.90)$ & $0.019^{*}$ & \\
\hline & Alleles & & & & & \\
\hline & $\mathrm{T}$ & 65(31.9\%) & $95(43.6 \%)$ & Reference & & \\
\hline & C & 139(68.1\%) & $123(56.4 \%)$ & $1.65(1.11-2.46)$ & $0.013^{*}$ & \\
\hline & rs2981579 & & & & & 0.196 \\
\hline & $\mathrm{T} / \mathrm{T}$ & $29(28.4 \%)$ & $25(22.9 \%)$ & Reference & & \\
\hline & $C / T$ & $38(37.3 \%)$ & $58(53.2 \%)$ & $0.57(0.29-1.11)$ & 0.096 & \\
\hline & $\mathrm{C} / \mathrm{C}$ & $35(34.3 \%)$ & $26(23.9 \%)$ & $1.16(0.56-2.43)$ & 0.692 & \\
\hline & Dominant model & 73(71.6\%) & 84(77.1\%) & $0.75(0.40-1.39)$ & 0.361 & \\
\hline & Recessive model & $67(65.7 \%)$ & $83(76.1 \%)$ & $0.60(0.33-1.09)$ & 0.095 & \\
\hline & Alleles & & & & & \\
\hline
\end{tabular}


Table 6 Genotypes of 8 SNPs of FGFR gene and their associations with adverse events (Continued)

\begin{tabular}{|c|c|c|c|c|c|c|}
\hline Target Gene & Polymorphisms/Genotype & $\begin{array}{l}\text { Toxicity(grade 3-4) } \\
N=102(48 \%)\end{array}$ & $\begin{array}{l}\text { No toxicity (grade1-2) } \\
N=109(52 \%)\end{array}$ & OR $(95 \% \mathrm{Cl})$ & $P$ & $P_{H W E}$ \\
\hline & T & $96(47.1 \%)$ & $108(49.5 \%)$ & Reference & & \\
\hline & C & $108(52.9 \%)$ & $110(50.5 \%)$ & $1.11(0.75-1.62)$ & 0.610 & \\
\hline & rs2981578 & & & & & 0.909 \\
\hline & $\mathrm{G} / \mathrm{G}$ & $30(29.4 \%)$ & $70(64.2 \%)$ & Reference & & \\
\hline & $A / G$ & $61(59.8 \%)$ & $29(26.6)$ & $4.91(2.65-9.08)$ & $<0.0001^{*}$ & \\
\hline & $\mathrm{A} / \mathrm{A}$ & $11(10.8 \%)$ & $10(9.1 \%)$ & $2.57(0.99-6.69)$ & 0.054 & \\
\hline & Dominant model & $72(70.6 \%)$ & 39(35.8\%) & $2.57(0.99-6.69)$ & $<0.0001^{*}$ & \\
\hline & Recessive model & $91(89.2 \%)$ & $99(90.8 \%)$ & $0.84(0.34-2.06)$ & 0.697 & \\
\hline & Alleles & & & & & \\
\hline & G & $121(59.3 \%)$ & $169(82.8 \%)$ & Reference & & \\
\hline & A & $83(40.7 \%)$ & $49(24.0 \%)$ & $2.37(1.55-3.61)$ & $<0.0001^{*}$ & \\
\hline \multirow[t]{9}{*}{ FGFR3 } & rs743682 & & & & & 0.682 \\
\hline & $\mathrm{G} / \mathrm{G}$ & 85(83.3\%) & $92(84.4 \%)$ & Reference & & \\
\hline & $A / G$ & $15(14.7 \%)$ & $17(15.6 \%)$ & $0.96(0.45-2.03)$ & 0.955 & \\
\hline & $\mathrm{A} / \mathrm{A}$ & $2(2.0 \%)$ & 0 & 0.00 & 0.999 & \\
\hline & Dominant model & $17(16.7 \%)$ & $17(15.6 \%)$ & $1.08(0.52-2.26)$ & 0.833 & \\
\hline & Recessive model & 100(98.0\%) & 109(100.0\%) & 0.00 & 0.999 & \\
\hline & Alleles & & & & & \\
\hline & G & 185(90.7\%) & $201(92.2 \%)$ & Reference & & \\
\hline & A & 19(9.3\%) & $17(7.8 \%)$ & $1.21(0.61-2.41)$ & 0.578 & \\
\hline \multirow[t]{9}{*}{ FGFR4 } & rs1966265 & & & & & 0.998 \\
\hline & $\mathrm{G} / \mathrm{G}$ & $22(21.6 \%)$ & 19(17.4\%) & Reference & & \\
\hline & $A / G$ & $46(45.1 \%)$ & $58(53.2 \%)$ & $0.69(0.33-1.42)$ & 0.307 & \\
\hline & $\mathrm{A} / \mathrm{A}$ & 34(33.3\%) & $32(29.4 \%)$ & $0.92(0.42-2.00)$ & 0.829 & \\
\hline & Dominant model & $80(78.4 \%)$ & $90(82.6 \%)$ & $0.77(0.39-1.52)$ & 0.449 & \\
\hline & Recessive model & 68(66.7\%) & 77(70.6\%) & $0.83(0.46-1.49)$ & 0.534 & \\
\hline & Alleles & & & & & \\
\hline & G & $90(44.1 \%)$ & $96(44 . \%)$ & Reference & & \\
\hline & $A$ & $114(55.9 \%)$ & $122(56.0 \%)$ & $1.00(0.68-1.46)$ & 0.987 & \\
\hline
\end{tabular}

OR odds ratio, $95 \% \mathrm{Cl}$ 95\% confidence interval, ${ }^{*} \mathrm{~A} P$ value $<0.05$ was considered ststistically significant

treatment [47]. Specially, overexpression of Arg388 significantly increased cell proliferation and changes in epithelial to mesenchymal transition markers compared with cells overexpressing the Gly388 allele in transfected colon cancer cells [47]. Although the amino acid change was estimated to be benign by PolyPhen (http://genetics.bwh.harvard.edu/pph2), the effects of the FGFR4 Val10 and Ile10 alleles on cancer cell biology such as proliferation and migration should also be examined in further investigation [48].

Recently, lots of studies have reported the association between rs2981578, rs2981579 and breast cancer risk in any genetic model [49]. For rs2981578, Chen et al. [37] revealed that $\mathrm{rs} 2981578$ are associated with a decreased risk of breast cancer, which is contrary to the previous reports $[35,50]$, indicating that the difference of the associations is due to different minor alleles among different ethnicities. Also, there are interactions between rs2981578 and the age, BMI, and family history of breast cancer. In the present study, rs2981578 A allele predicted the individual chemosensitivity to CET-based regimen of breast cancer patients compared with $G$ allele, manifesting it as a potential prognostic indicator in NCT efficacy of breast cancer.

Generally, the anthracyclines and taxanes are associated with some life-threatening side effects. The most worrisome toxicities are myelosuppression and cardiac toxicity [39]. Myelosuppression was usually measured in the form of neutropenia [51], it is noteworthy that patients with neutropenia are at risk of developing 
Table 7 Clinicopathological parameters analysis according to rs1966265 genetic polymorphism in breast cancer patients

\begin{tabular}{|c|c|c|c|c|c|}
\hline \multirow{2}{*}{$\begin{array}{l}\text { Clinicopathological } \\
\text { parameters }\end{array}$} & \multicolumn{5}{|c|}{ rs1966265(N = 90) } \\
\hline & GG & $A G \& A A$ & OR & $95 \% \mathrm{Cl}$ & $P$ \\
\hline \multicolumn{6}{|l|}{ T-status,n(\%) } \\
\hline$\leq \mathrm{T} 2$ & $3(3.3)$ & $3(3.3)$ & & & \\
\hline$>\mathrm{T} 2$ & $17(18.9)$ & $67(74.4)$ & 3.941 & $0.730-21.284$ & 0.111 \\
\hline \multicolumn{6}{|l|}{ N-status,n(\%) } \\
\hline $\mathrm{N} 0+\mathrm{N} 1$ & $15(6.7)$ & $55(61.1)$ & & & \\
\hline $\mathrm{N} 2+\mathrm{N} 3$ & $5(5.6)$ & 15(16.7) & 0.818 & $0.256-2.615$ & 0.735 \\
\hline \multicolumn{6}{|l|}{ Tumor grade } \\
\hline Gradell & $8(8.9)$ & $26(28.9)$ & & & \\
\hline Gradelll & $12(13.3)$ & $44(48.9)$ & 1.128 & $0.408-3.121$ & 0.816 \\
\hline \multicolumn{6}{|l|}{ ER } \\
\hline positive & $16(17.8)$ & $46(51.1)$ & & & \\
\hline negative & $4(4.4)$ & $24(26.7)$ & 2.087 & $0.628-6.941$ & 0.230 \\
\hline \multicolumn{6}{|l|}{$P R$} \\
\hline positive & $13(14.4)$ & $38(42.2)$ & & & \\
\hline negative & $7(7.8)$ & $32(35.6)$ & 1.564 & $0.557-4.390$ & 0.396 \\
\hline \multicolumn{6}{|l|}{ Her2-neu stastus } \\
\hline positive & $7(7.8)$ & $25(27.8)$ & & & \\
\hline negative & $13(14.4)$ & $45(50.0)$ & 0.969 & $0.342-2.744$ & 0.953 \\
\hline \multicolumn{6}{|l|}{ TNBC } \\
\hline Yes & $3(3.3)$ & 13(14.4) & & & \\
\hline No & $17(18.9)$ & $57(63.3)$ & 1.292 & $0.328-5.072$ & 0.713 \\
\hline \multicolumn{6}{|l|}{ P63 } \\
\hline positive & $2(2.2)$ & $1(1.1)$ & & & \\
\hline negative & $18(20.0)$ & $69(76.7)$ & 7.667 & $0.658-89.367$ & 0.104 \\
\hline \multicolumn{6}{|l|}{ Ki-67 } \\
\hline positive & $3(3.3)$ & $25(27.8)$ & & & \\
\hline negative & $17(18.9)$ & $45(50.0)$ & 0.318 & $0.085-1.190$ & 0.089 \\
\hline
\end{tabular}

$T$ tumor stage, $N$ nodes stage, TNBC triple negative breast cancer, Her 2 human epidermal growth factor receptor 2

life-threatening infections [43]. Patients experiencing febrile neutropenia during chemotherapy will often give rise to dose reductions or delays [44], and thus receive a potentially less effective treatment [52]. Also, cardiac toxicity limits the duration of drug treatment, particularly at high cumulative doses [53]. As a result, it is of great value to seek better predictive markers for identifying patients who are inclined to suffer from severe toxicity caused by chemotherapy.

Notably, our study revealed that the CC genotype of FGFR1 rs2420946 significantly increased the risk of CET-induced leucopenia, neutropenia and gastrointestinal toxicity in comparison to TT genotype. Meanwhile, FGFR2 rs1981578 was also associated with higher frequency of toxicities in dominant model. Thus far, only one previous study monitored the effect TT genotype of
FGFR4 rs351855 had a tendency toward higher incidence of febrile neutropenia during NCT. Charehbili et al. genotyped 187 DNA samples extracted from patients with stage II/III HER2-negative breast cancer. Of note, the study showed that patients with a TT genotype in rs351855 (FGFR4) may be at a tendency toward higher incidence of febrile neutropenia during neoadjuvant TAC chemotherapy [30]. It is our hope that this study will add the body of literature for prediction the FGFRs genetic polymorphisms lead to individual toxicities in response to CET-based regimen.

CET-containing agents exert cytotoxic effects through the creation of cyclophosphamide-DNA crosslinks and the induction of cell cycle arrest and ultimately apoptosis if not properly repaired. Ghayad et al. [54] showed that the PI3K/PTEN/AKT pathway has been linked to promotion of survival in breast cancer cells, resistance to chemotherapy, resistance to endocrine therapy, and has been associated with poor prognosis. Furthermore, Starska et al. [55] revealed that PI3K/PTEN/AKT is FGFs and their receptors' downstream regulator signaling pathway. Recently, genetic variations within the PI3K/PTEN/AKT have been reported to modulate clinical outcomes in esophageal cancer and lung cancer patients $[56,57]$. Thus, genetic variations in the genes encoding these important molecules may modulate signaling through this pathway and result in variation in the development of toxicity or clinical outcomes following CET-based therapy. To conclude, further investigation is needed to confirm the predictive values of FGFR polymorphism in PI3K/PTEN/AKT signaling pathway.

Due to the limited samples in the present trial, a well-designed study with a larger number of $\mathrm{BC}$ patients is needed to verify the predictive values of FGFR SNPs. To address this we are continuing to collect specimens from breast cancer patients to further validate our results as well as extending our studies to an independent patient cohort.

\section{Conclusion}

This study firstly provides evidence of significant association between FGFR genetic variants and the responsiveness of the breast cancer patients to CET chemotherapy. These data suggest 4 FGFR polymorphisms had a main effect on clinical responses and toxicities, and may be employed as candidate biomarkers for predicting clinical outcomes and achieving better prognosis in $\mathrm{BC}$ patients with CET regimen.

\section{Abbreviations}

ACT: adjuvant chemotherapy; AKT: protein kinase B; BMI: body mass index; CET: docetaxel, epirubicin and cyclophosphamide; CTCAE: Common Terminology Criteria for Adverse Events; FGFR: Fibroblast growth factor receptor; i.v.: intravenous injection; mTOR: the mammalian target of rapamycin; NACT: neoadjuvant adjuvant chemotherapy; NSCLC: nonsmall-cell lung cancer; P13K: phosphatidylinositol-3-kinase; PTEN: phosphatase and 
tensin homolog deleted on chromosome ten; RECIST: Response Evaluation Criteria in Solid Tumors; SNP: single nucleotide polymorphisms; TNBC: triplenegative breast cancer

\section{Acknowledgements}

Not applicable.

\section{Funding}

This study was supported by grants from the National Natural Science Foundation of China (81302853), Shanghai Municipal Commission of Health and Family Planning (201540261), Shanghai Medical and Health Development Fund (2015001) and Huashan Hospital North (2015107, 2015114). The funder had no role in the design of the study and collection, analysis, and interpretation of data and in writing the manuscript.

\section{Availability of data and materials}

The datasets used in this study contain personal information and are not publicly available, but may be available from the corresponding author on reasonable request, subject to ethical approvals.

\section{Authors' contributions}

LC and QYL contributed to the conception and design of the study. LC, HJQ and TY performed the statistical analysis and drafted and revised the manuscript. LC and HJQ collected blood samples. HJQ, HFC and LDZ performed the technical experiments. HXL and JS collected blood samples and clinical information. QYL and TY participated in the design of the study and collected the clinical information. MKZ and XJS supervised information collection and contributed to the analysis. All authors read and approved the final version of the manuscript.

\section{Ethics approval and consent to participate}

All patients filled the informed consent forms and agreed to have their samples used for research purposes. The procedures of this study were also approved by the Huashan Hospital Institutional Review Board. Approved No. of ethic committee was 2017-017.

\section{Consent for publication}

Not applicable.

\section{Competing interests}

The authors declare that they have no competing interests.

\section{Publisher's note}

Springer Nature remains neutral with regard to jurisdictional claims in published maps and institutional affiliations.

\section{Author details}

'Department of Pharmacy, Huashan Hospital, Fudan University, Shanghai, China. ${ }^{2}$ Department of Pathology, Huashan Hospital North, Fudan University, Shanghai, China. ${ }^{3}$ Department of General Surgery, Huashan Hospital North, Fudan University, Shanghai, China. ${ }^{4}$ Nursing Department, Huashan Hospital, Fudan University, Shanghai, China.

\section{Received: 21 November 2017 Accepted: 15 October 2018}

\section{Published online: 25 October 2018}

\section{References}

1. Torre LA, Bray F, Siegel RL, Ferlay J, Lortet-Tieulent J, Jemal A. Global cancer statistics, 2012. CA Cancer J Clin. 2015;65(2):87-108.

2. Yang G, Wang Y, Zeng Y, Gao GF, Liang X, Zhou M, Wan X, Yu S, Jiang Y, Naghavi $M$, et al. Rapid health transition in China, 1990-2010: findings from the global burden of disease study 2010. Lancet. 2013;381(9882):1987-2015.

3. Early Breast Cancer Trialists' Collaborative G. Effects of chemotherapy and hormonal therapy for early breast cancer on recurrence and 15year survival: an overview of the randomised trials. Lancet. 2005; 365(9472):1687-717

4. Sheu MJ, Hsieh MJ, Chiang WL, Yang SF, Lee HL, Lee LM, Yeh CB. Fibroblast growth factor receptor 4 polymorphism is associated with liver cirrhosis in hepatocarcinoma. PLoS One. 2015;10(4):e0122961.

5. Powers CJ, McLeskey SW, Wellstein A. Fibroblast growth factors, their receptors and signaling. Endocr Relat Cancer. 2000;7(3):165-97.
6. Liang G, Liu Z, Wu J, Cai Y, Li X. Anticancer molecules targeting fibroblast growth factor receptors. Trends Pharmacol Sci. 2012;33(10):531-41.

7. Terzuoli E, Corti F, Nannelli G, Giachetti A, Donnini S, Ziche M. Bradykinin B2 receptor contributes to inflammatory responses in human endothelial cells by the transactivation of the fibroblast growth factor receptor FGFR-1. Int J Mol Sci. 2018;19(9):2638

8. Regeenes R, Silva PN, Chang HH, Arany EJ, Shukalyuk Al, Audet J, Kilkenny DM, Rocheleau JV: Fibroblast growth factor receptor 5 (FGFR5) is a coreceptor for FGFR1 that is up-regulated in beta-cells by cytokine-induced inflammation. J Biol Chem. 2018:A118-3036. https://doi.org/10.1074/jbc. RA118.003036.

9. Wang C, Ke Y, Liu S, Pan S, Liu Z, Zhang H, Fan Z, Zhou C, Liu J, Wang F. Ectopic fibroblast growth factor receptor 1 promotes inflammation by promoting nuclear factor-kappaB signaling in prostate cancer cells. J Biol Chem. 2018:293(38):14839-49.

10. Hamamoto J, Yasuda H, Nonaka Y, Fujiwara M, Nakamura Y, Soejima K, Betsuyaku T. The FGF2 aptamer inhibits the growth of FGF2-FGFR pathway driven lung cancer cells. Biochem Biophys Res Commun. 2018;503(3):1330-4.

11. Hanze J, Kessel F, Di Fazio P, Hofmann R, Hegele A. Effects of multi and selective targeted tyrosine kinase inhibitors on function and signaling of different bladder cancer cells. Biomed Pharmacother. 2018;106:316-25.

12. Cao F, Wang S, Cao X, Liu X, Fu K, Hao P, Liu J. Fibroblast growth factor 21 attenuates calcification of vascular smooth muscle cells in vitro. J Pharm Pharmacol. 2017;69(12):1802-16.

13. Suyama K, Shapiro I, Guttman M, Hazan RB. A signaling pathway leading to metastasis is controlled by N-cadherin and the FGF receptor. Cancer Cell. 2002;2(4):301-14.

14. Xian W, Schwertfeger KL, Vargo-Gogola T, Rosen JM. Pleiotropic effects of FGFR1 on cell proliferation, survival, and migration in a 3D mammary epithelial cell model. J Cell Biol. 2005:171(4):663-73.

15. Massabeau C, Sigal-Zafrani B, Belin L, Savignoni A, Richardson M, Kirova YM, Cohen-Jonathan-Moyal E, Megnin-Chanet F, Hall J, Fourquet A. The fibroblast growth factor receptor 1 (FGFR1), a marker of response to chemoradiotherapy in breast cancer? Breast Cancer Res Treat. 2012;134(1):259-66.

16. Cui F, Wu D, Wang W, He X, Wang M. Variants of FGFR2 and their associations with breast cancer risk: a HUGE systematic review and metaanalysis. Breast Cancer Res Treat. 2016;155(2):313-35.

17. Kim S, Dubrovska A, Salamone RJ, Walker JR, Grandinetti KB, Bonamy GM, Orth AP, Elliott J, Porta DG, Garcia-Echeverria C, et al. FGFR2 promotes breast tumorigenicity through maintenance of breast tumor-initiating cells. PLoS One. 2013;8(1):e51671.

18. Tomlinson DC, Knowles MA, Speirs V. Mechanisms of FGFR3 actions in endocrine resistant breast cancer. Int J Cancer. 2012;130(12):2857-66.

19. Kuroso K, Imai Y, Kobayashi M, Yanagimoto K, Suzuki T, Kojima M, Ueda Y. Immunohistochemical detection of fibroblast growth factor receptor 3 in human breast cancer: correlation with clinicopathological/molecular parameters and prognosis. Pathobiology. 2010;77(5):231-40.

20. Tiong KH, Tan BS, Choo HL, Chung FF, Hii LW, Tan SH, Khor NT, Wong SF, See SJ, Tan YF, et al. Fibroblast growth factor receptor 4 (FGFR4) and fibroblast growth factor 19 (FGF19) autocrine enhance breast cancer cells survival. Oncotarget. 2016;7(36):57633-50.

21. Wiechec $E$, Hansen LL. The effect of genetic variability on drug response in conventional breast cancer treatment. Eur J Pharmacol. 2009;625(1-3):122-30.

22. Goke F, Franzen A, Menon R, Goltz D, Kirsten R, Boehm D, Vogel W, Goke A, Scheble $V$, Ellinger J, et al. Rationale for treatment of metastatic squamous cell carcinoma of the lung using fibroblast growth factor receptor inhibitors. Chest. 2012;142(4):1020-6.

23. Dutt A, Ramos AH, Hammerman PS, Mermel C, Cho J, Sharifnia T, Chande A, Tanaka KE, Stransky N, Greulich H, et al. Inhibitor-sensitive FGFR1 amplification in human non-small cell lung cancer. PLoS One. 2011;6(6):e20351.

24. Weiss J, Sos ML, Seidel D, Peifer M, Zander T, Heuckmann JM, Ullrich RT, Menon R, Maier S, Soltermann A, et al. Frequent and focal FGFR1 amplification associates with therapeutically tractable FGFR1 dependency in squamous cell lung cancer. Sci Transl Med. 2010;2(62):62ra93.

25. Dy GK, Mandrekar SJ, Nelson GD, Meyers JP, Adjei AA, Ross HJ, Ansari RH, Lyss AP, Stella PJ, Schild SE, et al. A randomized phase II study of gemcitabine and carboplatin with or without cediranib as first-line therapy in advanced non-small-cell lung cancer: North Central Cancer Treatment Group Study N0528. J Thorac Oncol. 2013;8(1):79-88.

26. Meng $\mathrm{QH}$, Xu E, Hildebrandt MA, Liang D, Lu K, Ye Y, Wagar EA, Wu X Genetic variants in the fibroblast growth factor pathway as potential 
markers of ovarian cancer risk, therapeutic response, and clinical outcome. Clin Chem. 2014;60(1):222-32.

27. Yermachenko A, Dvornyk V. UGT2B4 previously implicated in the risk of breast cancer is associated with menarche timing in Ukrainian females. Gene. 2016;590(1):85-9.

28. Kelleher FC, O'Sullivan $H$, Smyth E, McDermott R, Viterbo A. Fibroblast growth factor receptors, developmental corruption and malignant disease. Carcinogenesis. 2013;34(10):2198-205.

29. Frullanti E, Berking C, Harbeck N, Jezequel P, Haugen A, Mawrin C, Parise O Jr, Sasaki H, Tsuchiya N, Dragani TA. Meta and pooled analyses of FGFR4 Gly388Arg polymorphism as a cancer prognostic factor. Eur J Cancer Prev. 2011:20(4):340-7.

30. Charehbili A, de Groot S, van der Straaten T, Swen JJ, Pijl H, Gelderblom H, van de Velde CJ, Nortier JW, Guchelaar HJ, Kroep JR. Exploratory analysis of candidate germline gene polymorphisms in breast cancer patients treated with neoadjuvant anthracycline-containing chemotherapy and associations with febrile neutropenia. Pharmacogenomics. 2015;16(11):1267-76.

31. Jiang Y, Sun S, Wei W, Ren Y, Liu J, Pang D. Association of FGFR3 and FGFR4 gene polymorphisms with breast cancer in Chinese women of Heilongjiang province. Oncotarget. 2015;6(32):34023-9.

32. Eisenhauer EA, Therasse P, Bogaerts J, Schwartz LH, Sargent D, Ford R, Dancey J, Arbuck S, Gwyther S, Mooney M, et al. New response evaluation criteria in solid tumours: revised RECIST guideline (version 1.1). Eur J Cancer. 2009; 45(2):228-47.

33. National Cancer Institute NloH, U.S. Department of Health and Human Services. Common Terminology Criteria for Adverse Events (CTCAE) Version 4.0. Published May 28, 2009; Revised Version 4.03 June 14, 2010. (Vol Available from: https://ctep.cancer.gov/protocolDevelopment/electronic_ applications/docs/CTCAE_4.03.xlsx. Accessed 20 Nov 2016.

34. Allred DC, Harvey JM, Berardo M, Clark GM. Prognostic and predictive factors in breast cancer by immunohistochemical analysis. Mod Pathol. 1998;11(2):155-68.

35. Low SK, Takahashi A, Ashikawa K, Inazawa J, Miki Y, Kubo M, Nakamura Y, Katagiri T. Genome-wide association study of breast cancer in the Japanese population. PLoS One. 2013;8(10):e76463.

36. Coates AS, Winer EP, Goldhirsch A, Gelber RD, Gnant M, Piccart-Gebhart M, Thurlimann B, Senn HJ, Panel M. Tailoring therapies-improving the management of early breast cancer: St Gallen international expert consensus on the primary therapy of early breast Cancer 2015. Ann Oncol. 2015;26(8):1533-46.

37. Chen Y, Shi C, Guo Q. TNRC9 rs12443621 and FGFR2 rs 2981582 polymorphisms and breast cancer risk. World J Surg Oncol. 2016;14(1):50

38. Rastogi P, Anderson SJ, Bear HD, Geyer CE, Kahlenberg MS, Robidoux A, Margolese RG, Hoehn JL, Vogel VG, Dakhil SR, et al. Preoperative chemotherapy: updates of National Surgical Adjuvant Breast and bowel project protocols B-18 and B-27. J Clin Oncol. 2008;26(5):778-85.

39. Ejlertsen B. Adjuvant chemotherapy in early breast cancer. Dan Med J. 2016;63(5): B5222.

40. Marme F, Werft W, Walter A, Keller S, Wang X, Benner A, Burwinkel B, Sinn P, Hug S, Sohn C, et al. CD24 Ala57Val polymorphism predicts pathologic complete response to sequential anthracycline- and taxane-based neoadjuvant chemotherapy for primary breast cancer. Breast Cancer Res Treat. 2012;132(3):819-31.

41. Vekony H, Ylstra B, Wilting SM, Meijer GA, van de Wiel MA, Leemans CR, van der Waal I, Bloemena E. DNA copy number gains at loci of growth factors and their receptors in salivary gland adenoid cystic carcinoma. Clin Cancer Res. 2007;13(11):3133-9.

42. Wesche J, Haglund K, Haugsten EM. Fibroblast growth factors and their receptors in cancer. Biochem J. 2011:437(2):199-213.

43. Crawford J, Dale DC, Kuderer NM, Culakova E, Poniewierski MS, Wolff D, Lyman GH. Risk and timing of neutropenic events in adult cancer patients receiving chemotherapy: the results of a prospective nationwide study of oncology practice. J Natl Compr Cancer Netw. 2008;6(2):109-18.

44. Schwenkglenks M, Jackisch C, Constenla M, Kerger JN, Paridaens R, Auerbach L, Bosly A, Pettengell R, Szucs TD, Leonard R. Neutropenic event risk and impaired chemotherapy delivery in six European audits of breast cancer treatment. Support Care Cancer. 2006;14(9):901-9.

45. Camilleri M, Klee EW, Shin A, Carlson P, Li Y, Grover M, Zinsmeister AR. Irritable bowel syndrome-diarrhea: characterization of genotype by exome sequencing, and phenotypes of bile acid synthesis and colonic transit. Am J Physiol Gastrointest Liver Physiol. 2014;306(1):G13-26.
46. Wong BS, Camilleri M, Carlson P, McKinzie S, Busciglio I, Bondar O, Dyer RB, Lamsam J, Zinsmeister AR. Increased bile acid biosynthesis is associated with irritable bowel syndrome with diarrhea. Clin Gastroenterol Hepatol. 2012:10(9):1009-15 e1003.

47. Cho SH, Hong CS, Kim HN, Shin MH, Kim KR, Shim HJ, Hwang JE, Bae WK, Chung IJ. FGFR4 Arg388 is correlated with poor survival in resected Colon Cancer promoting epithelial to mesenchymal transition. Cancer Res Treat. 2017;49(3): $766-77$.

48. Li X, Zhang R, Liu Z, Li S, Xu H. The genetic variants in the PTEN/PI3KJAKT pathway predict susceptibility and CE(a)F chemotherapy response to breast cancer and clinical outcomes. Oncotarget. 2017;8(12):20252-65.

49. Zhang Y, Zeng X, Liu P, Hong R, Lu H, Ji H, Lu L, Li Y. Association between FGFR2 (rs2981582, rs2420946 and rs2981578) polymorphism and breast cancer susceptibility: a meta-analysis. Oncotarget. 2017;8(2):3454-70.

50. Cai Q, Zhang B, Sung H, Low SK, Kweon SS, Lu W, Shi J, Long J, Wen W, Choi $J$, et al. Genome-wide association analysis in east Asians identifies breast cancer susceptibility loci at 1q32.1, 5q14.3 and 15q26.1. Nat Genet. 2014;46(8):886-90.

51. Schwenkglenks M, Pettengell $R$, Jackisch $C$, Paridaens $R$, Constenla $M$, Bosly A, Szucs TD, Leonard R. Risk factors for chemotherapy-induced neutropenia occurrence in breast cancer patients: data from the INC-EU prospective observational European neutropenia study. Support Care Cancer. 2011;19(4):483-90.

52. Chirivella I, Bermejo B, Insa A, Perez-Fidalgo A, Magro A, Rosello S, GarciaGarre E, Martin P, Bosch A, Lluch A. Optimal delivery of anthracycline-based chemotherapy in the adjuvant setting improves outcome of breast cancer patients. Breast Cancer Res Treat. 2009;114(3):479-84.

53. Petrelli F, Borgonovo K, Cabiddu M, Lonati V, Barni S. Mortality, leukemic risk, and cardiovascular toxicity of adjuvant anthracycline and taxane chemotherapy in breast cancer: a meta-analysis. Breast Cancer Res Treat. 2012;135(2):335-46.

54. Ghayad SE, Cohen PA. Inhibitors of the PI3K/Akt/mTOR pathway: new hope for breast cancer patients. Recent Pat Anticancer Drug Discov. 2010;5(1):29-57.

55. Starska K, Forma E, Lewy-Trenda I, Stasikowska-Kanicka O, Skora M, Brys M. Fibroblast growth factor receptor 1 and 3 expression is associated with regulatory PI3K/AKT kinase activity, as well as invasion and prognosis, in human laryngeal cancer. Cell Oncol. 2018;41(3):253-68.

56. Pu X, Hildebrandt MA, Lu C, Lin J, Stewart DJ, Ye Y, Gu J, Spitz MR, Wu X. PISK/PTEN/AKT/mTOR pathway genetic variation predicts toxicity and distant progression in lung cancer patients receiving platinum-based chemotherapy. Lung cancer. 2011;71(1):82-8.

57. Hildebrandt MA, Yang $H$, Hung MC, Izzo JG, Huang M, Lin J, Ajani JA, Wu X. Genetic variations in the PI3K/PTEN/AKT/mTOR pathway are associated with clinical outcomes in esophageal cancer patients treated with chemoradiotherapy. J Clin Oncol. 2009;27(6):857-71.

\section{Ready to submit your research? Choose BMC and benefit from:}

- fast, convenient online submission

- thorough peer review by experienced researchers in your field

- rapid publication on acceptance

- support for research data, including large and complex data types

- gold Open Access which fosters wider collaboration and increased citations

- maximum visibility for your research: over $100 \mathrm{M}$ website views per year

At BMC, research is always in progress.

Learn more biomedcentral.com/submissions 